\title{
PROFESSOR EUGENIUSZ STANISLAW KRUSZEWSKI, DOCTOR HABILITATED - HISTORIAN, POLITICAL EMIGRANT, DIPLOMAT AND SOCIAL ACTIVIST
}

Eugeniusz Stanisław Kruszewski was born in Zbąszyń in 1929 in the family of Maksymilian Leon, a post office clerk and a participant of the Greater Poland (Wielkopolskie) Uprising, and Jadwiga, née Synak. After finishing primary school in Zbąszyń, he went to secondary schools in Wolsztyn and Wrocław, and in 1950 he passed the baccalaureate exam. After that exam he did a six-month military service in the School Company of Reserve Officers (Szkolna Kompania Oficerów Rezerwy); when he finished it he was sent to the Centre of Quartermaster Training (Centrum Wyszkolenia Kwatermistrzowskiego) in Poznań, where he studied finance at the Finance Faculty at the same time. After being promoted to the rank of second lieutenant he was assigned to the post of finance officer in the General Staff in Warsaw and - since 1954 - in the General Staff of the Navy in Gdynia. Released from the army in 1957 he started studying at the Higher School of Economics in Sopot and in 1962 he defended his Master's Dissertation and obtained the title of Master in Economics. In 1966 he commenced his doctoral studies at the Higher School of Agriculture in Poznan in the field of food technology. He spent part of his doctoral studies in Galliera Veneta in Milan, Italy, within an ad personam scholarship. In the years 1962-1969 he was a lecturer in the Secondary Vocational School of Food Industry and a clerk in the Federation of Grain and Milling (Zjednoczenie Zbożowo-Młynarski) in Gdańsk. When he

prof. dr hab. Bolesław Hajduk, emerytowany prof. Uniwersytetu Szczecińskiego, boleslaw.hajduk@ gmail.com. 
came back from Italy he was dismissed from his job without any justification and as soon as he got his passport he left Poland together with his family on October $16^{\text {th }}, 1969$ and settled in Denmark as a political émigré. In the years 1976-1993 he earned his living as a clerk in the Ministry of Science.

In the exile he continued cultivating his academic interests and resumed doctoral studies in the Institute of the Academy of Agriculture and Veterinary Science (Det Kongelige Veterinaer- og Landbohojskole) in Copenhagen, which he finished in 1974. At the same time he specialised in library science the fruit of which was a dissertation 'Bibliography of Danish Translations of Polish Belles-Lettres 1855-1969' (Polish: 'Bibliografia duńskich przekładów polskiej literatury pięknej 1855-1969'; Danish: 'Bibliografi over dansker oversaetelser fra polsk skonsklitteratur 1855-1969'); in 1979 he was conferred the title of Certified Librarian by the Royal School of Library and Information Science. As Eugeniusz S. Kruszewski was also interested in political science he undertook doctoral studies at the Faculty of Law and Political Science of the Polish University Abroad (Polski Uniwersytet na Obczyźnie) in London. On the basis of the dissertation 'Polish Settlement in Denmark 1893-1939' ('Problemy osadnictwa polskiego w Danii 1893-1939') he was conferred the title of doctor in political science. Afterwards, in 1980, he wrote and defended a postdoctoral (habilitation) dissertation 'The Danish Candidacy for the Polish Throne in 1674', obtaining the title of Docent (Reader). In 1985 he became full professor in the field of history and international relations at the Faculty of Law and Social Science, and since 1998 also full professor in the sphere of the history of Poland and general history at the Faculty of Humanities of the Polish University Abroad. He lectured on history, methodology, law and culture; he also conducted Master and doctoral seminars.

The main research fields of the Professor are: the history of the Polish emigration in Scandinavia, the history of international relations and the links between Poland and Scandinavia. The academic achievements of the Professor are impressive; they include 20 monographs, 40 dissertations in collective works, about 400 articles and academic reviews, and 35 biographical articles and entries in encyclopedic publications. In addition, he prepared over 200 publications for the general public in Europe and North America.

It should be emphasised that the Professor was very active in academic congresses, conferences and symposia, inter alia:

- in the European Congress of Lay Persons (Louvain-le-Neuve, 1976),

- the Symposium on the History of the Church in Lithuania (Rome-London, 1976), 
- the Symposium 'Baltic Europe in the Perspective of Global Change' (Warsaw University, 1993),

- the International Conference 'Scandinavia and the Baltic Countries' (Gdańsk, 1995),

- the conference Poland - Denmark (Gdańsk, 2003),

- the conference on the mutual penetration of cultures in the Baltic region, including Poland and Scandinavia (Lund, 2005),

- six symposia on Biographistics of the Polish community abroad (Brussels, Kielce, Cracow, Olsztyn, Rome and Vienna, Warsaw),

- the Congresses on the Present-Day Polish Science and Culture Abroad (London, 1970, 1985, 1995, 2014),

- the academic session 'Emigration Institutions versus Independent Culture in Poland' (Gdańsk IPN, 2010),

- the symposium 'Polish Eastern Borderlanders in the World' (Opole Polytechnic, 2012),

- the academic conference on the $30^{\text {th }}$ anniversary of the Polish-Scandinavian Institute (Gdańsk, 2015),

- the all-Poland Academic Conference 'Scandinavia - Poland. People, Politics, Economy and Culture' (Gdańsk, 2017),

- the international academic conference 'Polish Written Heritage in Foreign Collections' (Warsaw, 2017).

In 1985 the Professor demonstrated his engagement, energy and organisational skills while setting up the Polish-Scandinavian Institute, a scientific society independent of any state structures, and became its director, and - after changing the statute in 2006 - its president up till now. To become a member of the Institute the candidate has to be an academic worker, irrespective of their nationality or citizenship, specialising in questions concerning Poland or any other of the Baltic countries, especially the Scandinavian ones, who can speak Polish or any language of the Scandinavian ones. The staff of the Institute is composed of 10 members and 10 correspondents from various academic centres in Poland and abroad, who conduct research into Nordic countries and/or lecture on such questions. In accordance with its statute the Institute is engaged in activities in several spheres: the history of Polish emigration in Scandinavia, the question of mutual penetration of Polish culture and the ones of the Scandinavian countries, taking into consideration the Polish and Scandinavian contributions, the question of mutual political and economic relations of the present time, the problem of national 
minorities, the promotion of 'Solidarity' movement in the Nordic countries and their support for the democratic opposition in Poland, and biographistics, i.e. biographical entries of the Poles who have settled in the countries of Northern Europe. The activity of the president and the co-workers of the Institute was also visible in their participation in international conferences, lectures, and publications addressed to the general public and in initiating studies into source materials in order to sort out documentation on the martyring of the Poles murdered in Katyń and imprisoned in the camps built by the Hitlerian German Third Reich.

The Institute's journal was 'Rocznik Instytutu Polsko-Skandynawskiego' ('Yearbook of the Polish-Scandinavian Institute') published in the years 19852005; there were 20 volumes altogether. It was multilingual: Polish, Danish, Norwegian, Swedish and English. It was the place where distinguished Polish and foreign scholars presented the results of their research. The Journal dealt with the Polish emigration in Scandinavia and questions of politics, economy and culture, there were scientific reviews and reports of academic conferences and information on the activities of the Institute. Since the academic year 2005/2006 the Board has been publishing the 'Reports of the Polish-Scandinavian Institute', which contain information on the activities of the Institute, on its authorities, on its personal composition, on the academic achievements of its co-workers and on publications concerning Polish-Scandinavian questions.

In order to inspire, support and develop activities in the sphere of knowledge of the links between Poland and the Nordic countries and of the development of Scandinavian philology in Poland in 1995 on the initiative of Eugeniusz S. Kruszewski the Stanisław Sawicki Scientific Prize was established, granted for outstanding achievements in research, lecturing or organisation. Up to 2017 the Prizes were granted to G. Labuda, P. Urbańczyk, B. Piotrowski, Z. Ciesielski, G. Szelągowska, B. Sochańska, S. Ekdahl, L. Kjellberg and R. Pullat.

The national and patriotic activity of Eugeniusz S. Kruszewski, the aim of which was to make Poland regain the real independence and sovereignty, was really impressive. After settling in Denmark he actively joined the process of creating an all-Scandinavia organisation of Polish pro-independence associations that functioned in that country. In 1971 together with Father Jan Szymaszek and Olgierd Tadeusz Zalewski he created the Polish Social and Cultural Centre and the Polish Social and Cultural Council, the structures associated with the Central Organisation of POSK in London. In June 1973 on the initiative of Eugeniusz S. Kruszewski the Committee for Free Poland (KnRWP) was created; in 1977 its 
name was changed to the Chief Committee of Free Poles (KnWRP). The KnWRP functioned in Denmark and its headquarters were in Copenhagen, its branch offices - in Stockholm and in Oslo. Shortly afterwards there appeared the Chief Committee of Free Poles in Scandinavia, which was transformed into the Scandinavian Committee for Free Poland. The main task of the above mentioned organisations was to restore full independence and sovereignty to the Polish people. One of the example of the tangible actions taken was the creation of the Support Office and the Foundation of Free Poles; they were the organisations which actively participated in the campaigns to help the people persecuted in the Communist Poland by means of collections of money, food, clothes, medicines and by providing care for emigrants from Poland who arrived in Denmark and the other Scandinavian countries.

The same ideas - i.e. justification and promotion of free Poland also on the initiative of Eugeniusz S. Kruszewski - were behind the creation of another journal 'Kronika' ('Chronicle'); the first issue appeared in February 1971 with the motto 'May the good of the Republic be the highest law'. The Journal was opinion-forming and influenced the Polish emigrants not only in Scandinavia, as it was sent to all the important emigration centres and Polish libraries in Europe and all over the world. The Journal dealt with both historical and present-day problems, concerning both Poland and the Scandinavian states. In the years 1980-1985 the Journal concentrated on problems related to Solidarity; it informed of strikes of workers and repressions of the Polish authorities, of activists being detained and of the banning of the Independent Self-Governing Labour Union 'Solidarity' (NSZZ 'Solidarność'). Among the things to be found in the Journal there were leaflets and other information materials concerning the fight of the democratic opposition in Poland. The Journal also informed on the reaction both of the authorities and of the societies of the Scandinavian countries to the events in Poland.

On July $16^{\text {th }}$, 1976 Eugeniusz S. Kruszewski assumed the function of the Delegate of the Government and later the function of the Plenipotentiary of the Polish Government in Exile, with the Headquarters in Denmark, and those events were of utmost importance for pro-independence activity and maintaining the national awareness and patriotic activity in Scandinavia. The Delegate represented the Polish Authorities in Exile before the authorities of the Scandinavian countries, and kept in touch with the Polish diaspora in Denmark, Sweden and Norway.

It also should be noted that Eugeniusz S. Kruszewski participated in the creation and activities of the Society 'Pro Polonia' (created on May $3^{\text {rd }}$, 1977); its 
basic aim was to inform the Danish on the situation of the Polish in Poland, the repressions of the Polish authorities, the crime in Katyń, the effects of the Yalta Conference for the sovereignty of Poland and the programme of the democratic opposition and the NSZZ 'Solidarity'.

The description of the academic, organisational and patriotic achievements of Eugeniusz S. Kruszewski would be incomplete without the information on his social activities. Together with his wife Marta he supported Polish organisations related to the Polish Government in Exile, inter alia the Polish Social and Cultural Centre in London (donor since 1982), the Polish Institute and Museum of General Władysław Sikorski in London (perpetual member since 1984), the Józef Piłsudski Institute in London (perpetual member since 1985), the Polish Library in London (perpetual member since 1998), the John Paul II Foundation in the Vatican (benefactor since 1998), the Polish Catholic Mission and its Polish Library (in the years 1975-1985 he was president of its board).

The activities of Professor Eugeniusz S. Kruszewski were fully appreciated. Eugeniusz S. Kruszewski was decorated by the Polish Authorities in Exile in London with:

- the Polish Army Medal (1978),

- the Home Army Cross (1973),

- and the Golden Medal of the National Treasure (1984).

In addition he was given the following awards:

- the Golden Badge of the Polish Social and Cultural Centre (London, 1982),

- the Medal of the Polish Culture in Exile (1985, 1995),

- the Badge of the Knight of the International White Cross Organisation (Sydney, 1990),

- the Golden Badge of the Society of Polish Eastern Territories (London, 1991),

- the Golden Medal of the American Biographistic Institute (2006),

- the Literary Prize of the Federation of the Societies of Polish Veterans (London, 1992),

- the Prize of the Society of Polish Writers in Exile for the promotion of Polishness abroad (London, 2000),

- the Award of the Children Foundation 'In Time to Help' (Warsaw, 2002),

- the Title of Master of Science and the Honorary Membership of the Kashubian Institute (Gdańsk, 2016). 


\section{Bibliography of Professor Eugeniusz S. Kruszewski}

\section{Monographs}

Problemy osadnictwa Polaków w Danii 1883-1939 [English: Problems of Polish Settling in Denmark 1883-1939], London 1980.

Małe państwa w stosunkach międzynarodowych. Problemy naukowo-badawcze, London 1982.

Katyn. Kronikker om mordet på polske soldater i 1940 i Sovjetunionen. Udvalg foretaget af Eugeniusz S.Kruszewski. København [Copenhagen], Stockholm, 1984

Duńska kandydatura do polskiego tronu (1673-1674). Geneza i problem wyznaniowy, London 1985

Felicia. Det skandinaviske brudstykke af Kontinental Aktion, København [Copenhagen] 1988.

Akcja Kontynentalna w Skandynawii 1940-1945, Copenhagen 1992.

The Danish Candidature to the Polish Throne in 1674, 1995.

Katyn skoven og dens hemmeligheder, København 1996 (co-author Emil J.W. Ashøj).

Niemiecka myśl polityczna w XVIII wieku i małe państwo, London 1997.

Polski Instytut Źródłowy w Lund (1939-1972). Zarys historii i dorobek, London 2001

Mówia świadkowie Ravensbrück [Zeznania świadków z 1945]. Wstęp, wybór i opracowanie, Copenhagen 2001.

Bibliografia “Rocznika” IPS 1988-2001 (co-author Józef Jasnowski), Copenhagen 2002.

Bibliografia "Rocznika” IPS 1986-2005, Copenhagen 2007.

Ks. E. Ortved (1855-1930) oraz listy z lat 1894-1906 do bp. J. v. Eucha, Copenhagen 2003.

Joseph Jasnowski MCMVI XII III MMVI. Druk okolicznościowy, Copenhagen 2006.

Duńscy przyjaciele sprawy polskiej, Copenhagen 2006.

Polska polityka w raportach duńskich dyplomatów (1919-1926), Copenhagen 2008.

Polskie tropy nad Sundem i Skagerrakiem, Copenhagen 2009.

Fortcelinger om en svunden tid i Danmark [Om polske indvandere, tyske opsynsmænd og den katolske kirke i Danmark i det XX.årh.], København / Copenhagen 2012.

Na obrzeżach dyplomacji. Przedstawicielstwo Rządu RP w Danii 1976-1990, Copenhagen 2013.

W stużbie Polski i nauki. Instytut Polsko-Skandynawski w latach 1985-2015, Copenhagen 2015.

Prelekcje w Zbaszyniu 30 V- 4 VI 2016, Copenhagen-Zbąszyń 2016.

Listy znad Zatoki Świętego Franciszka, Copenhagen 2017. 


\section{Articles/studies/sketches in collective works}

Dwugtos o zachodniej granicy Polski w Roku Panskim 1930, [in:] Kaszubi - Pomorze-Gdańsk. W kręgu pytań o kulturę, historię i tożsamość. Księga Jubileuszowa Profesora Józefa Borzyszkowskiego z okazji 70. rocznicy urodzin, ed. C. ObrachtProndzyński, T. Rembalski, K. Lewalski, Gdańsk 2016, pp. 453-466.

Mine møde med Dr. Helge Tramsen. Katyn 1940. København, Stockholm, Katyn Komittén i Sverige, Pro Polonia i Danmark, Kronika forlaget,1984, pp. 25-27.

Madame Curie in Copenhagen, [in:] Maria Skłodowska Curie and Niels Bohr, ed. T. Głowacki, Copenhagen, Polish-Scandinavian Research Institute, 1990, pp. 128 154.

Polacy w kulturze Danii XIX i XX wieku, [in:] Z dziejów Polski i Skandynawii, eds. E. Ashøj, E.S. Kruszewski, Copenhagen, IPS, 1995, pp. 23-40.

Idacym w wiek XXI, [in:] U progu polskiej demokracji, ed. R. Iwan, Lublin-Kilonia 1994, pp. 205-221.

Europe of Regions and Regional Culture, [in:] Baltic Europe in the Perspective of Global Change. In Memoriam of Jean Christophe Oberg, ed. A. Kukliński, Oficyna Naukowa, Warszawa 1995, pp. 45-48; A Commentary from the Polish-Scandinavian Institute, Copenhagen (co-author Emil Ashøj), p. 49.

Działalność Instytutu Polsko-Skandynawskiego w Kopenhadze, [in:] Res Historica Booklet 1, Uniwersytet Marii Curie-Skłodowskiej, Lublin 1997, pp. 39-42.

Życiorys uratowany od zapomnienia (Kazimierz Rogala-Kosiński), [in:] Materiaty III Sympozjum Biografistyki Polonijnej (Rome 25-26 IX 1998), Czelej, Lublin 1998, pp. 208-215.

Fascynująca osobowość Polki i Artystki - Elżbieta Baumann (1819-1881), [in:] Materiaty IV Sympozjum Biografistyki Polonijnej (Vienna, 1-2 IX 1999), Czelej, Lublin 1999, pp. 142-149.

Krakowianina peregrynacja na Północ - Kazimierz Salewicz (1907-1993), [in:] Materiały V Sympozjum Biografistyki Polonijnej (Kraków, 22-23 IX 2000), Czelej, Lublin 2000, pp. 360-369.

Polacy w siłach zbrojnych monarchii duńskiej od połowy XVII do końca XVIII stulecia, [in:] Materiały VI Międzynarodowego Sympozjum Biografistyki (Mons/Brussels, 28-29 IX 2001), Kucharski, Toruń 2001, pp. 233-245.

Redemptorysta, który stawal w potrzebie. O. Jan Szymaszek (1901-1989), [in:] Materiaty VII Międzynarodowego Sympozjum Biografistyki Polonijnej (Rome, 17-18 X 2002), Kucharski, Toruń 2002, pp. 155-160.

12 September 2014 Polacy w Danii wobec pojattańskiej Polski (1944-1990), [in:] W stużbie Polsce i emigracji. Księga dedykowana Prof. E. Szczepanikowi, eds. L. Nowak, M. Szczerbiński, Gorzów Wlkp. 2002, pp. 161-171. 
Przedstawicielstwo dyplomatyczne Rządu RP na Uchodźstwie w Danii w latach 19761989, [in:] Z dziejów Polski i emigracji. Księga dedykowana b. Prezydentowi RP R. Kaczorowskiemu, eds. M. Szczerbiński, T. Wolsza, Gorzów Wlkp. 2003, pp. 355-369. Immigration and emigration until 1950, [in:] The Polish Cultural \& Scientific Heritage at the Dawn of the Third Millenium, ed. E. Szczepanik, Polish Society of Arts and Sciences Abroad, Polish Cultural Foundation, London 2003, pp. 85-94.

Tadeusz Jan Norwid-Nowacki (1902-1976) pisarz i działacz niepodległościowy, [in:] Pokolenia spetnionego obowiazku. Studia dedykowane profesorowi Józefowi Garlińskiemu, eds. J. Farys, R. Nir, M. Szczerbiński, Gorzów Wlkp. 2004, pp. 137-146. Relacje postów duńskich z Warszawy (1919-1923), [in:] Studia z dziejów Polski i Europy w XIX i XX wieku. Dedykowane profesorowi Piotrowi Stefanowi Wandyczowi, eds. J. Farys, R. Nir, M. Szczerbiński, Gorzów Wlkp. 2004, pp. 351-383.

Polska w świetle relacji postów duńskich z Warszawy (1919-1923), [in:] Polska - Dania w ciagu wieków, ed. J. Szymański, Gdańsk 2004, pp. 127-146.

Byśmy mogli żyć w wolności... [Polscy lotnicy polegli w Danii], [in:] Nadzieje, złudzenia, rzeczywistość. Studia z historii Polski XX wieku. Ksiega dedykowana prof. Tadeuszowi Wyrwie, eds. W. Hładkiewicz, M. Szczerbiński, Gorzów Wlkp. 2004, pp. 233-243.

Pobór Polaków w Danii do wojska austriackiego (1914-1915), [in:] Historia i Archiwistyka. Studia z dziejów Polski, Polonii i archiwistyki. Księga dedykowana ks. dr. Romanowi Nirowi, eds. J. Faryś, D.A. Rymar, M. Szczerbiński, Gorzów Wlkp. 2004, pp. $245-254$.

Geneza i działalność Instytutu Polsko-Skandynawskiego (1985-2005). I Kongres Polskich Towarzystw Naukowych na Obczyźnie 8-11 September 2005, ed. Małgorzata Święch-Płonka, Polska Akademia Umiejętności, Stowarzyszenie "Wspólnota Polska”, Kraków 2007, pp. 205-216.

Materiały do dziejów polskich bibliotek w Danii (1893-1990). Biblioteki polskie za granica. Przeszłość i współczesność, eds. M. Kalczyńska, D. Sieradzka, Wydawnictwo Uniwersytetu Śląskiego, Katowice 2007, pp. 115-124.

Charyzmatyczny bramkarz Peter Schmeichel. Rodacy na stadionach świata, [in:] Materiały X Międzynarodowego Sympozjum Biografistyki Polonijnej, Kielce 2007, pp. $127-131$.

W stużbie wolnej Polski. Instytut Polsko-Skandynawski (1985-2005). Skandinavien och Polen. Möten, relationer och ömsesidig påverkan, ed. B. Törnquist-Plewa, Lund 2007, pp. 89-110 (Slavica Lundensia vol. 23).

Towarzystwo Duńsko-Polskie w Danii ogniwem szerzenia wiedzy o Polsce 1928-1940. Skandinavien och Polen. Möten, relationer och ömsesidig påverkan, ed. B. Törnquist-Plewa, Lund, 2007, pp. 111-128 (Slavica Lundensia vol. 23). 
Stanisław Lubicz Sawicki w świetle listów i wspomnień, [in:] Stanisław Lubicz Sawicki in Memoriam 1907-2007, Instytut Polsko-Skandynawski, Copenhagen 2008, pp. 13-33.

26. Gdańskie refleksje, [in:] Gdy myślę Gdańsk..., Zrzeszenie Kaszubsko-Pomorskie, Instytut Kaszubski, Gdańsk 2009, pp. 31-33.

27. Første danske lektor ved Poznań Universitet, "Folia Scandinavica Posnaniensia" 2009, vol. 10, pp. 37-46.

Grundris af polske boghistorie i Danmark (1893-1990), [in:] Jeg vil løfte frelsens bager. Festskrift til biskop Czeslaw Kozon, eds. H. Clausen, B.A. Frosell, K. Toft Madsen, Sankt Andreas Bibliotek, København 2011, pp. 141-158.

Kaszuba z ulicy Kanclerskiej. Pro Memoria Gerard Labuda (1916-2010), ed. J. Borzyszkowski, Instytut Kaszubski, Gdańsk-Wejherowo 2011, pp. 215-228.

Harald Høffding i jego polscy korespondenci, [in:] Polsk-skandinaviska möten = Spotkania polsko-skandynawskie, ed. B. Törnquist-Plewa, Lund 2011, pp. 61-85 (Slavica Lundensia vol. 26).

Polska emigracja w Danii w łączności z Krajem (1945-1990), [in:] Materiały z Międzynarodowej Konferencji Naukowej "Niepodległościowe uchodźstwo polskie w Europie i na świecie i jego rola w pomocy krajowi po układzie jałtańskim 1945-1990”. 2324 X2009 w Warszawie, pp. 162-173 (Internet edition).

Śladami polskiego apostolstwa w Danii (1893-1990), [in:] W nieustannej trosce o Polske i diaspore. Tom dedykowany ks. Abp. Szczepanowi Wesolemu, eds. R. Nir, M. Szczerbiński, K. Wasilewski, Stowarzyszenie Naukowe "Polska w Świecie", Gorzów Wlkp. 2012, pp. 149-164.

Imigracja i emigracja do roku 1950, [in:] Polskie dziedzictwo kultury i nauki. U progu trzeciego tysiaclecia, ed. E. Szczepanik, Wydawnictwo Naukowe Uniwersytetu Mikołaja Kopernika, Toruń 2012, pp. 89-98.

O duńskiej policji i jej muzeum w Kopenhadze, [in:] Policjanci. Numer specjalny. Materiaty Międzynarodowego Sympozjum. Muzealnictwo, archiwistyka, kolekcjonerstwo $i$ wystawiennictwo policyjne. Historia i współczesność, Józef Siwek, Kielce 2013, pp. 201-204.

Żołnierz, artysta, malarz i pisarz - Marian Hełm Pirgo, [in:] Kresowianie w świecie, ed. M. Kalczyńska, Instytut Śląski, Opole 2013, pp. 146-154.

Instytut Polsko-Skandynawski a niezależna nauka i kultura w kraju, [in:] Emigracja a środowiska kultury niezależnej w kraju, ed. S. Flis, Bydgoszcz-Gdańsk 2014, pp. 47-58.

Wiolonczelistka z Bożej łaski Halina Kowalska (24 December 1913 Suwatki - 14 February 1998 Copenhagen), [in:] Rodacy na Światowej pięciolinii. Polska kultura muzyczna na obczyźnie materiały, eds. Z. Judycki, T. Skoczek, Fundacja Polonia Semper Fidelis, Warszawa 2015, pp. 149-155. 
Artysta grafik - filozof. Piotr Baro - Łabużek (1924-1998), [in:] Świat według Baro polski artysta z Danii, Toruń Muzeum Uniwersyteckie, Archiwum Emigracji, 2015, p. 7.

Powrót do Kraju, którego nigdy nie opuściliśmy. Profesorowi Józefowi Borzyszkowskiemu dedykuję, [in:] Sztambuch przyjacielski Józefa Borzyszkowskiego, ed. C. Obracht-Prondzyński, Gdańsk 2016, pp. 102-103.

Archiwum i Ksiegozbiór naukowego Instytutu Polsko-Skandynawskiego, [in:] Z badań nad ksiązka i zbiorami historycznymi. Polonika w zbiorach obcych. Tom specjalny, eds. J. Puchalski, A. Chamera-Nowak, D. Pietrzkiewicz, Warsaw 2017, pp. 329-336.

Lwowski zestaniec - polskim księgarzem i wydawca w Londynie (Jerzy Kulczycki), [in:] Lwowianie w świecie. Referaty sympozjalne, eds. J. Gmitruk, Z. Judycki, T. Skoczek, Warsaw 2017, pp. 123-128.

\section{Yearbook of the Polish Scientific Society in Exile (1981-2010)}

Duńska kandydatura do tronu polskiego w 1674 r. na tle polityki europejskiej, 1982, Vol. 25, pp. 59-64.

Marselius a konflikt polsko-rosyjski za Jana Kazimierza, 1986, Vol. 29, pp. 73-81.

Państwa Pólnocy a chrystianiazacja Litwy, 1988, Vol. 30, pp. 108-131 (also: II Rocznik IPS, Copenhagen 1988, pp. 1-23).

Relacja z Międzynarodowego Kolokwium papieskiej Komisji Historii Kościoła dla uczczenia 600 letniej rocznicy chrztu Litwy (24-26.VI 1987), 1988, Vol. 30, pp. 100-106.

Akcja Kontynentalna w II Wojnie Światowej a problemy naukowo-badawcze, 1991, Vol. 33, pp. 62-68.

Dania wobec Polski i Szwecji w 1616, 1992, Vol. XXXIV, pp. 52-58.

Georg Brandes - przyjaciel Polski, 1992, Vol. XXXV, pp. 47-52.

Also: Tydzień Polski 3, London, 16 January 1993, p. 13.

Nekr. Śp. Prof. Józef Parnas 1909-1998, 1998, Vol. XLI, pp. 20-23.

List. Jubileusz XXV-lecia Towarzystwa Polskiego w Danii, 1998, Vol. XLI, pp. 260-261.

Nekr. Żegnamy czlowieka wielu nazwisk (Jan Karski), 1999, Vol. XLII, pp. 23-26.

Badania naukowe i ideologia nacjonalistyczna, 1999, Vol. XLII, pp. 61-66.

12. September 2014. List. Dotyczacy prof. Jerzego Zubrzyckiego, 2000, Vol. XLIII, pp. 287-288.

Z dziejów dyplomacji II Rzeczypospolitej Władysław Neuman (1891-1945), 2002, Vol. XLV, pp. 129-146.

Nekr. Homo Artifex. (Śp. Mieczystaw Paszkiewicz), 2003, Vol. XLVI, pp. 21-24.

List. Odznaczenie Medalem Pro Meritis, 2003, Vol. XLVI, pp. 400-401.

Muzeum Polskie w Raperswilu przed 130 laty, 2004, Vol. XLVII, pp. 123-132. 
Rec. Mikołaj Pawliszczew, Tygodnie polskiego buntu, transl. and ed. A. Zawilski, Dom Wydawniczy Bellona, Warsaw 2003, Vol. I-II, [in:] 2004, Vol. XLVII, pp. 384-394, reprinting from "Gazeta Niedzielna" London, 9.01.2005, no. 2, p. 4.

Rec. Teki Historyczne vol. XXIII, Polskie Towarzystwo Historyczne w Wlk. Brytanii, Londyn 2004. p. 345, [in:] 2004, Vol. XLVII, pp. 397-400, reprinting from "Tydzień Polski”, London, 1.01.2005, p. 17.

Patriarcha historyków polskich (Prof. Józef Jasnowski), 2005, Vol. XLVIII, pp. 45-52.

Niezwykte jubileusze seniora historyków polskich (Prof. Józef Jasnowski), 2005,

Vol. XLVIII, pp. 52-57, reprinting from “Tydzień Polski”, London, 12.03.2006, no. 11, p. 5.

XX-lecie Instytutu Polsko-Skandynawskiego (1985-2005), 2005, Vol. XLVIII, pp. 101-120.

Duńskiego slawisty spotkanie z Krakowem w Roku Pańskim 1842, 2006, Vol. XLIX, pp. 102-122.

Bibliografia Józefa Jasnowskiego, 2007, Vol. L, pp. 68-90.

Nekr. Memoriae Sacrae Professor Zdislavus Wataszewski, "Rocznik PTNO" 2007, Vol. L, pp. 36-40.

Nekr. Śp. Józef Jasnowski (12.03.1906-9.10.2009), “Rocznik PTNO” 2009, Vol. LII, pp. 18-22.

Nekr. Wspomnienie o Prezydencie Ryszardzie Kaczorowskim, "Rocznik PTNO" 2009, Vol. LII, pp. 22-26.

Unia Duńsko-Norweska wobec rozbiorów i Konstytucji 3 Maja, "Rocznik PTNO” 2010,

Vol. LIII, pp. 18-24.

Kongresy Kultury Polskiej na Obczyźnie w obronie wolnej nauki polskiej, "Rocznik PTNO” 2014, Vol. LVI, pp. 157-181.

Andrzej Żaki i Alma Mater Niepodlegtościowej Emigracji, "Rocznik PTNO” 2017, Vol. LIX, pp. 30-40.

\section{Yearbook of the Polish-Scandinavian Institute 1985-2005}

Wroga agentura, 1985/1986, Vol. I, pp. 13-16.

Państwa Pótnocy a chrystianizacja Litwy, 1986/1987, Vol. II, pp. 1-23.

Położenie katolików w krajach skandynawskich od pierwszej polowy XVI do połowy XIX wieku, 1987/1988, Vol. III, pp. 18-26.

Państwa nordyckie w czasie wizyty apostolskiej Ojca świętego Jana Pawła II czerwiec 1989, 1988/1989, Vol. IV, pp. 4-8.

Położenie Kościoła w Danii w latach 1849-1953, 1988/1989, Vol. IV, pp. 25-29.

Polacy w duńskim kościele katolickim w latach 1893-1989, 1988/1989, Vol. IV, pp. 30-36.

Nekrolog, który poruszyt świat, 1989/1990, Vol. V, pp. 38-46. 
Na zachodniej rubieży, 1989/1990, Vol. V, pp. 66-69.

Bibliografia prac i pism profesora Kazimierza Slaskiego (1947-1987), 198919/90, Vol. V, pp. 87-94.

Caspar Wilhelm Smith i jego powiazania z Polska w XIX w., 1990/1991, Vol. VI, pp. 19-36.

Europa wielonarodowej wspótpracy, 1991/1992, Vol. VII, pp. 4-13.

September 2014 Georg Brandes, przyjaciel Polski, 1992/1993, Vol. VIII, pp. 19-25.

Til Docent Emil Ashøj, 1994/1995, Vol. X, pp. 48-49.

Polakkerne i de skandinaviske landes historie og kultur, 1995/1996, Vol. XI, pp. 55-68.

Nestorowi historyków Józefowi Jasnowskiemu, 1995/1996, Vol. XI, pp. 69-72.

Til æresmedlem Tadeusz Głowacki, 1995/1996, Vol. XI, p. 73.

Polakken Daniel Chodowiecki (1726-1801) i skandinaviska leksika, 1998/1999, Vol. XIV, pp. 87-100.

De kristne og Jøderne under den anden verdenskrig, 2000/2001, Vol. XVI, pp. 17-27.

Til Baros kunstudstilling 27.08.2001, 2000/2001, Vol. XVI, pp. 33-36.

Jak Redemptorysta "stawat w potrzebie”. O. Jan Tomasz Szymaszek (1901-1989), 2001/2002, Vol. XVII, pp. 15-52.

Maria Skłodowska-Curie z wizyta w Kopenhadze, 2003/2004, Vol. XIX, pp. 43-56.

W stużbie wolnej nauki, 2004/2005, Vol. XX, pp. 10-29.

\section{Articles in Academic Journals}

Stan i potrzeby badań nad emigracja polska w Danii, [in:] Symposiones Tomus, Vol. I, Polski Uniwersytet na Obczyźnie, London 1981, pp. 215-223.

Larsen i moralność komunistyczna, “Orzeł Biały” 1981, July-August, pp. 11-12.

Przem. Przemówienie podczas pożegnalnej kolacji na zakończenie Kongresu Kultury Polskiej na Obczyźnie 20 September 1985, "Ojczyzna w sercach. Prace Kongresu” 1986, Vol. I, Polskie Towarzystw Naukowe na Obczyźnie, London, pp. 113-114.

"Felicja" - skandynawski fragment Akcji Kontynentalnej, [in:] Nowoczesna historia Polski, ed. J. Jasnowski, Polskie Towarzystw Naukowe na Obczyźnie, London 1987, pp. 195-224 ("Prace Kongresu Kultury Polskiej na Obczyźnie” 1985, Vol. III, London 14-20.09.1985).

Naukowa i polityczna współpraca polsko-duńska w 2. połowie XIX w., "Zapiski Historyczne", 1994, no. 4, pp. 46-49.

Mine samtaler med dr Tramsen, [in:] Katyn skoven og dens hemmeligheder, Polsk-Skandinavisk Forskningsinstitut, København1996, pp. 61-69.

Działalność Instytutu Polsko-Skandynawskiego w Kopenhadze, "Res Historica" 1997, no. 1, pp. 39-42. 
Nekr. dr med. Stanistaw Jan Kasina (1913-1997), “Archiwum Historii i Filozofii Medycyny" 1998, Vol. 61, issue 1, pp. 110-111.

Dania. Akcja niepodlegtościowa na terenie międzynarodowym 1945-1990, ed. T. Piesakowski, Polskie Towarzystw Naukowe na Obczyźnie, London 1999, pp. 297-325.

Problemy małych archiwów na przykładzie Instytutu Polsko-Skandynawskiego, [in:] Materiaty XXI sesji Stałej Konferencji Muzeów, Archiwów i Bibliotek polskich na Zachodzie. 23-26.09.1999, ed. M. Jagosz, Fundacja Jana Pawła II, Rome-Cracow 1999, pp. 139-146.

Daniel Chodowiecki w skandynawskich leksykonach, "Acta Cassubiana" 1999, Vol. I, pp. 361-367.

September 2014 Polski Instytut Źródlowy w Lund w latach 1945-1946, "Prace Naukowe Rady Porozumiewawczej Badań nad Polonią" 2000, Vol. 3, pp. 84-96.

Nekr. Śp. Jørgen Lønborg Friis Mogensen (3.04.1909 Aalborg - 26.08.2000 Svaneke), "Acta Cassubiana" 2000, Vol. II, pp. 451-454.

Sympozjum Kultury Wolnych Polaków w Danii. Fragment dziatalności niepodległościowej, "Prace Naukowe Rady Porozumiewawczej Badań nad Polonią" 2000, Vol. 4, pp. $180-184$.

Nekr. Odszedt z klanu chorych na wolna Polskę. Tadeusz Andrzej Glowacki (1917-2001), [in:] Archiwum Emigracji, UMK, Toruń 2001, issue 4, pp. 267-268.

Artysta grafik - filozof. Piotr Labużek (1924-1998), [in:] Archiwum Emigracji, UMK, Torun 2001, issue 4, pp. 272-274.

Konfraternia "Złotej Róży”, [in:] Archiwum Emigracji, UMK, Toruń 2001, issue 4, pp. 297-300.

Ksiadz Edward Ortved (1855-1930) - opiekun Polaków w Danii, "Acta Cassubiana" 2002, Vol. IV, pp. 7-89.

Nekr. Niestrudzony czlowiek czynu, Jørgen Lønborg Mogensen (1909-2000), "Acta Cassubiana" 2003, Vol. V, pp. 369-371.

Polacy w historii i kulturze krajów skandynawskich, "Studia Historyczne" 2003, Vol. XLVI, issue 3-4 (182-182), pp. 403-420.

Kali czyli magia pędzla. Hanna Gordziałowska-Weynerowska (1919-2000), [in:] Archiwum Emigracji, UMK, Toruń 2003, issue 5-6, pp. 360-362.

Z. Opacki, Oficyna Naukowa, Warsaw 2003. p. 236, "Acta Cassubiana" 2004, Vol. VI, pp. 367-370.

Dyplomata II Rzeczypospolitej - Władysław Neuman (1891-1945), "Rocznik Gdański" 2004, Vol. 64, issue 1/2, pp. 33-42.

List. dot. artykułu Adama Redzika, Wydziat Prawa Uniwersytetu Lwowskiego w latach 1939-1945 ("Rocznik Lwowski” 2004, pp. 91-125), "Rocznik Lwowski” 2005, Vol. XI, pp. 243-244. 
Maria Skłodowska-Curie z wizyta w Kopenhadze. Nowotwory, "Journal of Oncology" 2005, Vol. 55, no. 3, pp. 264-269.

Rec. Listy ks. B. Sychty i prof. G. Labudy do Lecha Bątkowskiego, ed. L. Pszczółkowska, W. Kiedrowski, Oficyna Czëc, Gdańsk 2006. p. 70, Kaszubskie trio, "Acta Cassubiana" 2006, Vol. VIII, p. 338.

Duńskiego slawisty spotkanie z Krakowem w Roku Pańskim 1842, "Studia Historyczne" 2007, Vol. L, issue 3-4 (199-200), pp. 349-362.

Pomnik Jana Pawła II w Brzuchowicach, "Rocznik Lwowski" 2007, pp. 231-234.

Nekr. Memoriae sacra Zdislavus Wałaszewski, "Acta Cassubiana” 2008, Vol. X, pp. 350353.

Prawno-polityczne podstawy prawowitej władzy Rzeczypospolitej Polskiej na obczyźnie w latach 1939-1990, "Przegląd Polsko-Polonijny" 2011, no. 2, pp. 52-68.

Biogr. Józef Jasnowski, [in:] Wieluński Stownik Biograficzny, eds. Z. Szczerbik, Z. Włodarczyk, Vol. 1, Wieluńskie Towarzystwo Naukowe, Wieluń 2012, pp. 54-56.

Żołnierz - uczony - polityk. Jerzy August Bolesław Odrowąż-Gawenda (1917-2000), "Przegląd Polsko-Polonijny" 2012, no. 3, pp. 403-415.

Wsp. Sopocka Alma Mater, "Acta Cassubiana” 2013, Vol. XV, pp. 178-187.

Obchody 500-lecia Mikołaja Kopernika w Danii, "Zeszyty Naukowe Polskiego Uniwersytetu na Obczyźnie” 2014, Seria trzecia, no. 2, pp. 27-37.

Rec. Pro memoria Jan Piepka (1926-2001), ed., introduction, commentary J. Borzyszkowski, Instytut Kaszubski, Gdańsk 2013, p. 800, “Acta Cassubiana 2014, Vol. 16, pp. 323-325.

Korespondencja Jana Karskiego z Instytutem Polsko-Skandynawskim, Londyn, "Zeszyty Naukowe Polskiego Uniwersytetu na Obczyźnie" 2015, Seria Trzecia, no. 3, pp. 327-346.

Pomarcowa emigracja z PRL. Na przyktadzie uchodźstwa do Danii, "Przegląd Zachodni" 2016, no. 1 (358), pp. 193-198.

Instytut Polsko-Skandynawski i Pomorze, “Acta Cassubiana” 2015, Vol. XVII, pp. 213 225.

Rec. Frank Meisler, Zaułkami pamięci, Instytut Kaszubski, Gdańsk-Londyn-Jaffa, Gdańsk 2014, p. 344, "Acta Cassubiana" 2015, Vol. XVII, pp. 288-290.

Kaszubi w polskiej organizacji "Felicja” w Danii (1940-1945), "Acta Cassubiana" 2016, Vol. XVIII, pp. 169-187.

Det polske sprogsmal i dansk lyrik (1914-1917), "Slavica Lundensia" 2017, Vol. 28, pp. 113-125.

Listy znad Zatoki świętego Franciszka, [in:] Archiwum Emigracji, UMK, Toruń 2015, issue (1-2), pp. 22-23; 2017, pp. 235-256. 


\section{Editorial Works}

Kronika poświęcona sprawom polskim (monthly) Copenhagen-Oslo-Stockholm 19711985.

Notatki skandynawskie, 1988-1990.

Notatki Towarzystwa Polskiego, 1991-2000.

Rocznik Instytutu Polsko-Skandynawskiego, Copenhagen 1986-2005.

Sprawozdania Instytutu Polsko-Skandynawskiego, Copenhagen 2006.

Katyn 1940, Stockholm-København 1984.

J. Mogensen, Obserwacje duńskiego dyplomaty w Polsce 1939, IPS, Copenhagen 1994.

Z dziejów Polski i Skandynawii. Fra Polens og Nordens Historie, IPS, Copenhagen 1995.

J. Mogensen, Den store gidseltagning. Sidste akt 1945, IPS, Copenhagen 1996.

J. Mogensen, Die grosse Geiselnahme. Letzter Akt 1945, IPS, Copenhagen 1997.

“Pamiętnik Literacki”, Związek Pisarzy Polskich na Obczyźnie, Londyn 1999.

Mówią świadkowie Ravensbrück, IPS, Copenhagen 2001.

J. Jasnowski, Poland in the eyes of the Western Travellers during the Period of Grand Tour 1550-1850, IPS, Copenhagen 2008.

Stanisław Lubicz Sawicki in Memoriam 1907-2007, IPS, Copenhagen 2008.

Edition: dr Elżbieta Later-Chodyłowa 